\title{
Analysis on External Circumstances for the Development of Chinese Real Estate Finance
}

\author{
Yiran Tao \\ School of Architecture, the Chinese University of Hong Kong, Hong Kong, China \\ tyr031890@gmail.com
}

\begin{abstract}
Real estate finance as a branch of finance accompanied with the real estate industry, strategy is a global response to adapt to the change of external environment. The Research and development of Chinese real estate finance strategies is inseparable from the objective analysis of the domestic and international environment of real estate finance development. In this paper, the author analyze the development of domestic and international environment of China's real estate finance deeply. The status quo such as Chinese economic structural contradictions of China's urbanization strategy, domestic and international financial reform and international financial complexity and so on, have formed the external environment which Chinese real estate finance development strategy must be facing.
\end{abstract}

Keywords: real estate; finance; environmental analysis.

\section{Introduction}

Real estate finance theory is a branch finance theory which is generate in the real estate sector because of the interaction between finance and the economy to deepen in the development of Finance. With the frequent crisis of Chinese urbanization, economic financialization, financial globalization, financial complexity and the financial, real estate finance theory has become a major concern in the field of financial theory and research. However, with the analysis of the literature and the results of theoretical research of real estate financial, we can find that there are more studies of the technical level of real estate financing and real estate finance, but the studies relate to basic theoretical of the nature and function of real estate finance are less. So that the presence study of real estate finance theory is not deep and state enough, it is difficult for the formation of theoretical system which is suitable for the development of urbanization and China's real economy and be able to explain and predict the practice of Chinese real estate finance systematically and effectively.

Without an objective analysis and sober comprehensive cognition of the domestic and foreign environment of the process of urbanization. The cycle of Economic and financial theory cannot understand China's real estate financial systematically and clearly. According to the need of deepening real estate finance practice and theoretical, the domestic and foreign environment of Chinese real estate finance development was deeply analyzed.

\section{Domestic environmental analysis}

From the analysis of Chinese domestic environmental, after 35 years of market-oriented reform since 1978, china has made the world's attention to its achievements of economic and social development. China forward towards the world's largest economy, but in the process of urbanization, China also faced with an aging population, economic structural imbalances, the potential to increase the risk of asset bubbles and other issues.

\subsection{Continued economic growth in China, but the serious economic imbalances}

Through Productivity and demographic dividend released by economic reform since 1978, China has maintained sustained growth of more than $8 \%$ in the 35 years of development, and will be the world's largest economy. The average annual GDP growth rate is 9.89 percent in 1978-2010. The GDP in 2010 is equivalent to 20.57 times in 1978. The growth rate is $9.9 \%$ in the 30 years of $1978-$ 2008 , among the 166 countries around the world, China's growth is fastest. While the coefficient of 
variation of GDP is 0.28 , and it's the minimum of the world's 20 fastest growing economies [1]. China entered the economic structural adjustment area in 2014, and in this year the economic growth from $8.1 \%$ down to $7.5 \%$, in 2015 the economic growth from $7.8 \%$ down to $7.3 \%$. In the next 10 years the annual growth rate may be 6.5 percent, and the growth rate will be decreased, but still maintain a sustained growth trend.

Accompany with the sustained economic growth are the economic structural imbalances and weak domestic consumption. The most important economic structural imbalances are "high savings, low consumption" structural imbalance. High savings is not only the high savings rate of residents, but also have some other reasons. firstly, the Saving rate of government and state-owned enterprises account for the management system of state-owned enterprises; secondly, because of export-oriented policies, economic growth depends on foreign markets, domestic consumption was suppressed; imperfect social security system affect the consumption impulse residents; high real estate prices and the purchase of savings limits restrict immediate consumption; the income distribution system is imperfect, the source of income of residents is single and the growth rate is slowly and so on, this problems are all be limiting factors of residents' consumption and Chinese traditional industry overcapacity. According to, a survey of an authorities in 2013, among the 3545 sample enterprises, $71 \%$ of enterprises believe that the current overcapacity, $67.7 \%$ of enterprises believe that it will take more than three years to digest excess capacity, $22.7 \%$ of enterprises believe that it will take more than five years [2]. In the economic structure adjustment area, if Overcapacity problems cannot be solved and realize the transition quickly, there will be bankruptcy, and even trigger financial risks.

\subsection{The gradual emergence of the aging population in China, lack of capacity to pay family housing}

One of the advantages of the reform in the past 35 years is that China has young and cheap labors. Cheap labor provide a low-cost human resources for the investment and industrial development. And in the environment of economic stability, the young labor force maintained a high savings rate created the conditions for savings into capital. With the improvement of the implementation of China's population policy, living conditions and health conditions, the life of people was extended, and China's population gradually entered the aging stage. According to the standard determined by experts that the population of 65 years are old, in 2000, the proportion of China's elderly population have been $7 \%$, reached the standard of the United Nations about "aging society". By 2020 this proportion will rise to $11.2 \%$ [3]. Population aging will reduce the supply of labor in China's economic development in the future, driving up labor costs. And population aging will increase the pension gap, the motivation of provision for the aged will affect the transformation of savings into capital. Meanwhile, the Chinese housing prices are high ranking historically, middle and below income residents accounted for 50\% of the urban population. From 1998 to 2011, the disposable income of urban residents grew 4.02 times, far lower than the GDP growth and revenue growth, and their growth ratio are 5.38 times and 9.5 times respectively. The income growth is slow while the housing affordability still insufficient. At the same time, the housing structure is also imbalance. The rate of affordable housing for the commercial housing dropped to $4.8 \%$ in 2011 from $21.8 \%$ in 2000. Lower-middle class buyers remains difficult to buy a house, which will increase the unstabilizing factors in community.

\subsection{Real estate market trends to be polarized, the potential risk of asset bubbles is increasing}

After 15 years' rapid development, Chinese real estate market entered in a long period of adjustment period in 2013. With the restructuring of the economy, the real estate market Show the tendency of differentiation. Due to the industry gathering, strong employment absorption capacity, Perfect public facilities, the supply and demand in the real estate market of First-tier cities and second-tier cities remains strong and still in an expanded state. But in three-tier cities and four-tier cities, due to the industry lags behind, industry aggregation is not strong enough, under the existing taxation mechanisms, the government is still artificially increase the intensity of investment and land supply. The supply and demand relationship between and real estate are relaxed. The status of oversupply is still widespread, the high vacancy rate of a large number of projects and "ghost town" 
still exist, which showing the foam of real estate in three-tier and four-tier cities. Economic restructuring brought about industrial restructuring and the bankruptcy of some companies and industry exit, and the real estate industry is facing deep structural adjustment. Real estate projects and areas, which Lack of industrial supporting ability and employment absorption capacity, is facing a high probability to adjust real estate. Real estate prices in deep adjustment will bring asset bubbles and pressure on the potential risk of the financial crisis.

\subsection{Misallocation of financial resources, liquidity risks and financial risks}

In the case of the non-rational development of real estate industry, Simple pursuit of GDP growth, economic development, inadequate sophisticated financial management system lead to the formation of a mismatch of financial resources, industrial structure imbalance, highlighting the liquidity risk and financial risks. Financial resources are the core resources and determine the configuration of the other resources. There is a serious imbalance in the allocation of financial resources over the past 10 years of economic development. Unreasonable taxation system and government performance evaluation mechanism contribute to the formation of local land finance and debt. By the end of June 2013, Chinese governments at all levels to assume the debt of 30.3 trillion RMB, accounting for $36.7 \%$ ratio of GDP, and this proportion present a growth trend. Funding strand breaks appear on some local financing platform and made the risk of local debt crises increased. From the entire economic system, the financial resource misallocation embodied in huge monetary aggregates, the ratio of M2 and GDP is nearly $200 \%$. Affected by the misallocation of financial resources, a lot of money to invest in invest in the real estate industry and infrastructure and other fields directly or indirectly rather than Industrial, or even to maintain the operation of the capital chain. Which strengthened the financial fragility and increased financial risks.

\section{3. foreign environmental analysis}

\subsection{The conflict that China is an economic giant as well as a financial weaker country}

The rapid and sustained development of China's economy in the past 35 years of reform made China's total GDP into the significant position of the second largest economy in 2011. Which lead to some countries in the world, especially developed countries coveted China strategically, the public voice of the appreciation of Chinese RMB, the sudden and spread of foreign military events such as Diaoyu Island and etc., the Chinese problems complicate world political and economic. But at the same time China is still a financial weak country, RMB is not freely convertible international currency, China's exchange rate needs to be relative to the fixed in other major currencies, major international currency countries has a great influence and restriction on China's monetary policy, so that our monetary policy lack of adequate independence, the size of China's financial market is small and the degree of internationalization is low. To a large extent, our country did not establish uniform pricing system with international financial products. The pricing power and the right to speak are not enough. The ratio of financial assets to GDP is raised to $297 \%$ in 2007, but The United States and Japan's per capita financial assets are China's 36 and 38 times respectively [4]. There is still a distance between China's financial strength and the United States and other developed countries. This makes China's financial reform and direction not only single financial or economic issues in the level of domestic financial market or financial system reform, but also strategic issues involved in global political, economic and military structure, and even related to China next 10-20 years of sustainable development gradually.

\subsection{The conflict between Domestic resource scarcity and weak control right of international resource}

As mentioned above, China is a country with limited per capita resources. In the development of urbanization and industrialization, the resource has become the biggest bottleneck for sustainable development. In the international arena, relative concentration of the important natural resources including food and geographical location and the concentration of some developed countries' upstream control of natural resources, are all make China stand in a passive position in the global 
allocation of natural resources. In the event of natural disasters or conflict in the global economy, China's economy will pay a high cost and price because of the manipulation of Resource-rich countries. And even the food crisis and the oil crisis will appear.

\subsection{The conflict between Financial Development and systemic financial risks}

Economic globalization and financialization will inevitably lead to the globalization of finance, and will form global systemic financial risks. Systemic financial risk is derived from the financial system and will impact on the overall economy's volatility significantly. From the global economic crisis in 1929-1933, the 1980s financial crises in Latin America, the Asian financial crisis in 1997 to the US subprime mortgage crisis in 2008, all the risk are systemic financial risk and give rise to the country's economy and social life devastating, long-term impact respective.

The ratio of Chinese financial assets to GDP has risen to $297 \%$ in 2007 and the absolute value are as much as $\$ 100,000$. And china's money stock become the first in the world. At the same time, Money, as a wealth of claims, can through a variety of financial resources channel flow into every corner of the world, including the field of China's assets. And it will bring foams of Chinese assets, impact the normal operation of financial institutions, and even affect the overall economic and social development of our country. Therefore, since the 21st century, the intense competition of world market economy make "monetary and financial war" frequent. And the financial has risen to national development strategies and has become the core area of the regional competition.

\section{Conclusion}

Research on the topic of real estate finance theory is under complex background of Chinese urbanization, economic financialization, financial globalization and financial. The rapid development of real estate finance practice has brought the needs of theory of deepening and innovation. According to the needs of real estate finance practice and theoretical deepening, the author analyze domestic and international environment of Chinese real estate finance development deeply. The status quo of China's urbanization strategy, such as Chinese economic structural contradictions, domestic and international financial reform and the complexity of international financial and so on, have formed the external environment that Chinese real estate finance development strategy must face.

\section{References}

[1] Hu Angang, Yan Yilong, Wei Xing, 2030 China towards common prosperity [M], Beijing: China Renmin University Press, 2011.

[2] Liu Shijin, the formation of the new normal growth in the reform [M], Beijing: CITIC Publishing House, 2014, 16.

[3] National Population Development Strategy Research Group National population development strategy research report [M]. Publisher unknown, 2005.

[4] Xia Bin, Chen Daofu. China Financial Strategy 2020 [J]. Banker, 2011 (3): 22-22. 